\title{
Tumour necrosis factor gene polymorphisms are associated with COPD
}

\author{
M.R. Gingo*, L.J. Silveira", Y.E. Miller", A.L. Friedlander", G.P. Cosgrove\#, \\ E.D. Chan ${ }^{\star * \#, \oplus, ~ L . A . ~ M a i e r ~}{ }^{\#}$ and R.P. Bowler ${ }^{\#}$
}

ABSTRACT: Tumour necrosis factor (TNF)- $\alpha$ has been shown to be an important factor in animal models of chronic obstructive pulmonary disease (COPD). However, human studies of TNF polymorphisms in COPD have been equivocal.

Six TNF single nucleotide polymorphisms (-1031C/T, -863C/A, -857C/T, -237G/A, -308G/A and $+487 \mathrm{G} / \mathrm{A}$ ) and their haplotypes were investigated in 423 Caucasian smokers (298 patients with spirometric evidence of COPD and 125 without airflow obstruction).

The -308 minor allele (A) had a higher odds ratio (OR) of being associated with COPD in multivariate analysis (controlling for age, sex, pack-yrs; OR 1.9, 95\% confidence interval $(\mathrm{CI}) 1.1-$ 3.2) and was also associated with worse forced expiratory volume in one second/forced vital capacity. The -237 minor allele (A) had a lower OR of being associated with COPD (OR 0.40, 95\% $\mathrm{CI}$ 0.19-0.86). In COPD patients, the -857 minor allele (T) had a lower OR of being associated with severe stages of COPD (Global Initiative for Obstructive Lung Disease stage III and IV versus stage I and II, OR $0.46,95 \% \mathrm{CI} 0.24-0.88)$. Other TNF single nucleotide polymorphisms were not associated with COPD but the $-1031 /-863$ haplotype CC/TC had a lower OR in COPD patients versus smoking controls (OR $0.22,95 \% \mathrm{Cl} 0.05-0.97$ ).

The present study adds further evidence that tumour necrosis factor genotypes play a role in susceptibility to cigarette smoke.

KEYWORDS: Gene polymorphism, genetics, smoking

hronic obstructive pulmonary disease (COPD) develops in only $25-40 \%$ of cigarette smokers [1]. However, risk factors for susceptibility to COPD in smokers have not been completely determined. $\alpha_{1}$ Antitrypsin deficiency, which is the best documented genetic risk factor for COPD, accounts for only an estimated $1-2 \%$ of cases [2,3]. Other host factors are suspected to be involved in the remaining $98-99 \%$ of cases.

One candidate susceptibility gene for COPD is tumour necrosis factor (TNF), the gene coding for the protein that is processed to TNF- $\alpha$. In mice, TNF- $\alpha$ overproduction has led to pulmonary emphysema and inflammation [4, 5] and is thought to drive $\sim 70 \%$ of cigarette smoke-induced emphysema and inflammation $[6,7]$. TNF- $\alpha$ may exert its effects by stimulating the release of other enzymes, such as macrophage metalloelastase [8]. In COPD patients, there is a higher concentration of TNF- $\alpha$ in bronchial biopsies [9], induced sputum [10] and bronchoalveolar lavage fluid (BALF) compared with control subjects [11]. TNF- $\alpha$ levels in sputum are also increased significantly during acute exacerbations of COPD $[12,13]$. A recent meta-analysis found an association between COPD and elevated serum TNF- $\alpha$ levels [14]. In contrast, healthy smokers have no increase in TNF- $\alpha$ in BALF $[11,15]$ and their alveolar macrophages have a decreased release of TNF- $\alpha[16,17]$.

The factors that lead to increased TNF- $\alpha$ in COPD patients but not in smokers with normal lung function are unknown. One possibility is that TNF expression is regulated by single nucleotide polymorphisms (SNPs) in the gene. For instance, increased transcriptional activity of the TNF gene has been associated with the $-308 \mathrm{~A}$ allele in various disorders [18-23]. The TNF -863A allele has been associated with increased gene [24] and TNF- $\alpha$ expression from peripheral blood mononuclear cells [25]. The -857T and -1031C alleles have been associated with increased transcriptional activity of the TNF gene [25]. The -237A
AFFILIATIONS

*Dept of Medicine, University of Colorado at Denver and Health Sciences Center

\# Dept of Medicine, National Jewish Medical and Research Center, and "Dept of Medicine, Denver Veterans Affairs Medical Center, Denver, C0, USA.

CORRESPONDENCE

R.P. Bowler

Division of Pulmonary Medicine Dept of Medicine National Jewish Medical and Research Center 1400 Jackson Street Room K715a

Denver

CO 80206 USA

Fax: 13032702249

E-mail: BowlerR@njc.org

Received:

August 032007

Accepted after revision: January 232008

SUPPORT STATEMENT

This study was supported by the Kenneth Monfort Foundation, the Flight Attendant Medical Research Institute (Miami, FL, USA), Specialized Program of Research Excellence In Lung Cancer (University of Colorado Cancer Institute, Aurora, CO, USA) grant CA58187 and General Clinical Research Centre/National Institutes of Health grant M01 \#RR000051.

STATEMENT OF INTEREST None declared. 
allele has shown mixed results in association with TNF- $\alpha$ protein production [26-28].

Despite these promising in vitro studies, not all of these SNPs have been studied in COPD populations and those that have been studied often have conflicting results (table 1). These inconsistencies may be due to study design limitations such as small number of subjects, genotyping with a limited number of informative SNPs, lack of haplotyping with multiple SNPs, failure to adjust for confounding variables, such as age, and lack of comparison to healthy smoking controls, the most relevant comparison group. In the present study some of these limitations were addressed by genotyping six TNF SNPs with biological activity in a large number of subjects with welldefined physiological phenotypes. Multivariate analysis was also used and TNF- $\alpha$ genotype/haplotype associations with COPD were examined.

\section{METHODS}

\section{Selection and description of participants}

All subjects were studied under protocols approved by the Institutional Review Board at the National Jewish Medical and Research Center (Denver, CO, USA) or the Colorado Multiple Institution Institutional Review Board (Denver, CO, USA), with guidelines recommended by the National Institutes of Health (Bethesda, MD, USA). Signed informed consent was obtained for all subjects. Control subjects were healthy volunteers recruited from the local community by word of mouth and advertising, had no report of respiratory symptoms or disease and had a smoking history $>20$ pack-yrs. Patients with COPD were recruited from an outpatient pulmonary clinic. The diagnosis of COPD was made using Global Initiative for Obstructive Lung Disease (GOLD) criteria [49] using a post-bronchodilator forced expiratory volume in one second (FEV1) after the onset of full expiration compared FEV1 $\%$ predicted for age, sex and ethnicity based on a sample of the general population of the USA [50]. GOLD state I patients (FEV1/forced vital capacity (FVC) $<0.7$ and FEV1 $\geqslant 80 \%$ pred) were included as cases. Patients with emphysema on highresolution computed tomography and normal pulmonary function test $(n=11)$ were placed in GOLD stage I for analysis (table 2).

\section{Blood collection}

A total of $6 \mathrm{~mL}$ of blood was withdrawn from the antecubital vein into a sterile $13 \times 1,000-\mathrm{mm}$ sodium heparin Vacutainer Plus (BD, Franklin Lakes, NJ, USA). The sample was immediately centrifuged at $2,100 \times g$ for $10 \mathrm{mins}$ at room temperature. The buffy coat was removed and stored at $-80^{\circ} \mathrm{C}$.

\section{DNA extraction/isolation and genotyping}

Buffy coats were used to extract DNA using QIAamp 96 DNA Blood Kit (QIAGEN, Valencia, CA, USA), and the DNA was eluted with nuclease-free water. A total of six SNPs were tested in all subjects. The polymorphisms $-1031 \mathrm{~T} / \mathrm{C},-863 \mathrm{C} / \mathrm{A}$ and $-857 \mathrm{C} / \mathrm{T}$ were tested using PCR conditions and primers as previously described [51]. Direct haplotypes were also tested using two pairs of primers for $-857 \mathrm{C} / \mathrm{T}$ with $-237 \mathrm{G} / \mathrm{A}$ and -308G/A with +488G/A as previously described [51, 52]. Each SNP was analysed using a sequence specific primer to detect the presence of that SNP.

\section{Data analysis}

Genotype frequencies of each polymorphism in the case and control populations were evaluated for departures from Hardy-Weinberg equilibrium, using Chi-squared tests $(p<0.001)$. Tests for genotypic differences between cases and controls were conducted in the context of logistic regression, univariately and multivariately (adjusting for sex, age and smoking pack-yrs, where appropriate). A dominant model was used for the genetic analysis. Caucasians accounted for the vast majority of subjects and, thus, it was the only group analysed in the present study. Univariate and multivariate linear regression models were used to assess the influence of genotypes on cross-sectional continuous severity outcomes (FEV1 \% pred and FEV1/FVC). Normalising transformations were performed on continuous outcome variables when necessary to better approximate model assumptions. For analysis of severity, GOLD stage was dichotomised to a mild-to-moderate (GOLD stage I or II) and severe disease (GOLD stage III or IV). Genotypic differences between cases with severe and mild-to-moderate disease were evaluated in the context of logistic regression univariately and multivariately. The measures of linkage disequilibrium, $d^{\prime}$ and $R^{2}$, were calculated using Haploview (Copyright 2003-2005 Whitehead Institute for Biomedical Research, Cambridge, MA, USA). In addition, Haploview was also used to determine haplotype blocks using the confidence interval method [53].

Haplotype frequencies were estimated using Haplo.Score [54]. This software uses an expectation maximisation-based algorithm to calculate the posterior probability of each possible haplotype combination for each individual when haplotype phase is unknown. In order to adjust for the uncertainty in haplotype assignments, a weighted logistic regression model was used. Each subject could appear in the dataset more than once, with each entry weighted by the probability of that haplotype combination for that individual, so that the total contribution of each individual was one observation. Both haplotype combination and single haplotype effects were tested for the presence of a specific haplotype pair versus no presence and for carrying at least one specified haplotype versus not carrying the specified haplotype.

\section{RESULTS}

\section{Demographics}

The COPD and control groups were significantly different in FEV $1 \%$ pred $(45.0 \pm 19$ and $98.5 \pm 18 \%$ for COPD and controls, respectively; $\mathrm{p}<0.0001$; table 2 ). Compared with COPD patients, control subjects were more likely to be male, but had a similar smoking history (in pack-yrs). Only Caucasians were analysed in the present study to minimise the effects of population stratification.

\section{TNF SNP genotypes}

TNF genotype frequencies are listed in table 3. A genotype with the -308 minor allele (GA or AA) was significantly more frequent in COPD patients than in control subjects in both univariate (odds ratio (OR) 1.9, 95\% confidence interval (CI) $1.1-3.2 ; \mathrm{p}=0.03$ ) and multivariate analyses (OR 1.9, 95\% CI 1.1$3.4 ; \mathrm{p}=0.03$; table 4$)$. There was significantly less chance of having the genotype with the -237 minor allele (GA or AA) in 


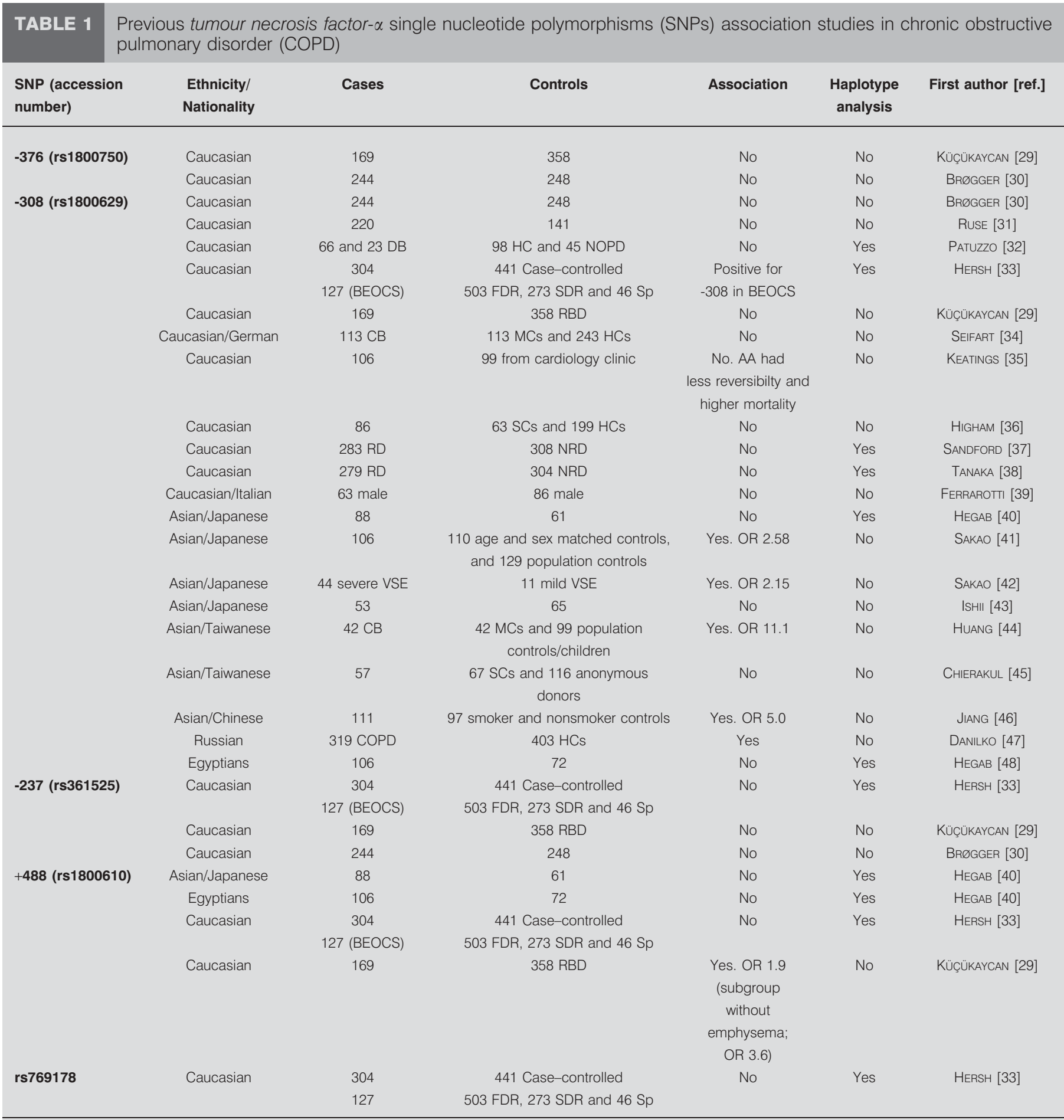

DB: disseminated bronchiectasis; HC: healthy control; NOPD: nonobstructive pulmonary disease; BEOCS: Boston early onset chronic obstructive pulmonary disease; FDR: first degree relative; SDR: second degree relative; Sp: spouse; RBD: random blood donors; MC: matched controls; SC: smoker control; RD: rapid decline in forced expiratory volume in one second (FEV1); NRD: non-RD; OR: odds ratio; VSE: visual score for emphysema; $\mathrm{CB}$ : chronic bronchitis.

COPD patients than control subjects by multivariate analysis (OR 0.40, 95\% CI 0.19-0.86; $\mathrm{p}=0.02$; table 4).

A genotype with a minor allele for the -857 SNP (CT or TT) had a statistically significant lower OR in COPD subjects with severe COPD (GOLD stage III and IV) compared with those with mild-moderate COPD (stage I and II) in both univariate (OR 0.5, 95\% CI 0.26-0.95; $\mathrm{p}=0.03$ ) and multivariate analyses (OR 0.46, 95\% CI 0.24-0.88; $\mathrm{p}=0.02$; supplementary table S3). No association was found with any of the genotypes and FEV1 


\begin{tabular}{|c|c|c|c|}
\hline & COPD & Control & $p$-value \\
\hline Subjects n & 298 & 125 & \\
\hline Age yrs & $65.6 \pm 9.8$ & $58.7 \pm 10.4$ & $<0.0001$ \\
\hline Male \% & 52.0 & 70.3 & 0.0007 \\
\hline $\begin{array}{l}\text { Smoking history } \\
\text { pack-yrs }\end{array}$ & $55.2 \pm 30$ & $52.3 \pm 26$ & 0.34 \\
\hline FEV $1 \%$ pred & $45.0 \pm 19$ & $98.5 \pm 18$ & $<0.0001$ \\
\hline FEV $1 /$ FVC & $0.48 \pm 0.13$ & $0.72 \pm 0.09$ & $<0.0001$ \\
\hline
\end{tabular}

$\%$ pred (data not shown), although the -308 genotype (GG) was associated with a higher mean FEV1/FVC (supplementary table S4). There were no statistically significant associations with COPD for SNPs $-1031,-863$ and +488 .

\section{Haplotype analysis}

Haplotype blocks were constructed according to the confidence interval method of GABRIEL et al. [53] in cases and

\begin{tabular}{l}
$\begin{array}{l}\text { TABLE } 3 \\
\begin{array}{l}\text { Genotype frequencies of tumour necrosis factor } \\
\text { (TNF)- } \alpha \text { single nucleotide polymorphisms (SNPS) }\end{array} \\
\begin{array}{l}\text { TNF SNPs (accession } \\
\text { number) and genotype }\end{array}\end{array}$ COPD" $^{\#}$ Control \\
\hline
\end{tabular}

\begin{tabular}{|c|c|c|}
\hline \multicolumn{3}{|c|}{-1031 (rs1799964) } \\
\hline TT & $195(65.4)$ & $83(66.4)$ \\
\hline TC & $93(31.2)$ & $36(28.8)$ \\
\hline $\mathrm{CC}$ & $10(3.4)$ & $6(4.8)$ \\
\hline \multicolumn{3}{|c|}{-863 (rs1800630) } \\
\hline $\mathrm{CC}$ & $219(73.5)$ & $94(75.2)$ \\
\hline CA & $72(24.2)$ & 29 (23.2) \\
\hline AA & $7(2.3)$ & $2(1.6)$ \\
\hline \multicolumn{3}{|c|}{-857 (rs1799724) } \\
\hline $\mathrm{CC}$ & $253(84.9)$ & $103(82.4)$ \\
\hline CT & $44(14.8)$ & $21(16.8)$ \\
\hline$\pi$ & $1(0.3)$ & $1(0.8)$ \\
\hline \multicolumn{3}{|c|}{-308 (rs1800629) } \\
\hline GG & $220(73.8)$ & $105(84.0)$ \\
\hline GA & $67(22.5)$ & $18(14.4)$ \\
\hline AA & $11(3.7)$ & $2(1.6)$ \\
\hline \multicolumn{3}{|c|}{-237 (rs361525) } \\
\hline GG & $277(93.0)$ & $110(88.0)$ \\
\hline GA & $20(6.7)$ & $13(10.4)$ \\
\hline AA & $1(0.3)$ & $2(1.6)$ \\
\hline \multicolumn{3}{|c|}{$+488($ rs1800610) } \\
\hline GG & $264(90.1)$ & $116(94.3)$ \\
\hline GA & $28(9.6)$ & $7(5.7)$ \\
\hline$A A$ & $1(0.3)$ & $0(0.0)$ \\
\hline
\end{tabular}

Data are presented as $\mathrm{n}(\%)$. COPD: chronic obstructive pulmonary disease. \#: $n=298 ; ": n=125$.
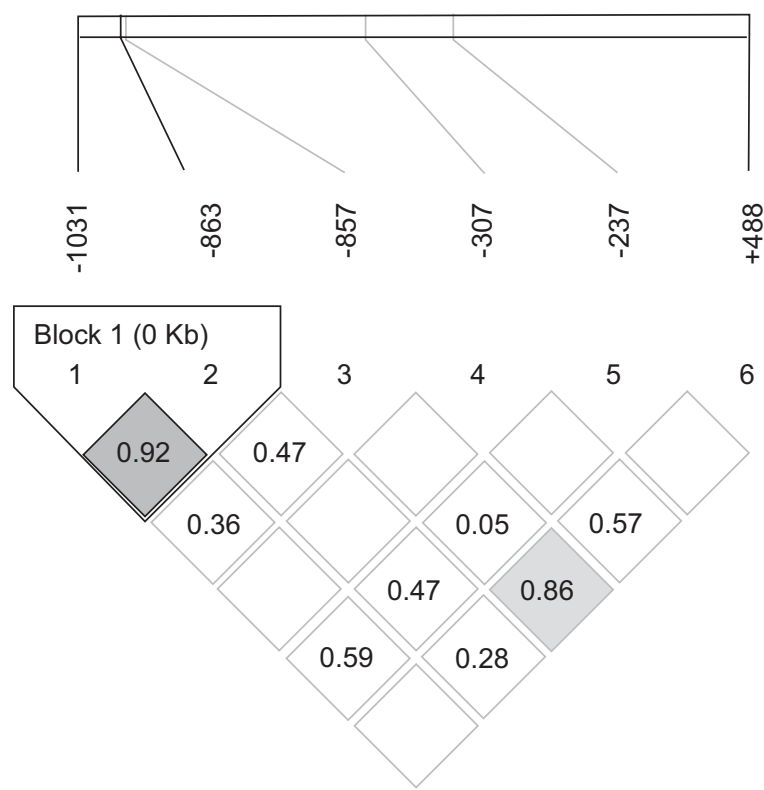

FIGURE 1. Linkage disequilibrium plot of tumour necrosis factor haplotypes. Haplotypes were constructed from genotyping data from Caucasians using the Gabriel block method [53]. Significant d' values are shown. There was only one block of SNPs (-1031 and -863).

controls separately using Haploview. This method uses both an estimate of $\mathrm{d}^{\prime}$ and a measure of its precision (confidence bounds) to construct haplotype blocks (fig. 1). Blocks with pairwise $\mathrm{d}^{\prime}<1$ have actual $\mathrm{d}^{\prime}$ values in the squares. Although the estimated pairwise linkage disequilibrium (LD) between many of the SNPs was high, the precision of the estimates was not high enough to fulfill the criteria for construction of haplotype blocks utilising all the SNPs. The estimate of LD between the -1031 SNP and the -863 SNP was the only estimate that had sufficient precision to warrant construction of a haplotype block. The estimated frequencies can be found in supplementary table S5. There were no haplotypes associated with COPD (data not shown).

\section{Meta-analysis of the -308 and -237 SNPs in COPD}

In order to put the present results in perspective, a search of the online database PubMed for previously reported frequencies of TNF SNPs was performed. For the -308 SNP, data was extracted from all the studies listed in table 1, except for one that did not report frequencies for case and control separately [31], two that only reported rapid decliners with no cases [37, 38] and one that only reported emphysema in COPD subjects [42]. Combining the present data with the remaining 16 studies (a total of 610 cases and 1,612 controls), a genotype with the -308 minor allele was found to have an $\mathrm{OR} \pm$ SE of $1.28 \pm 0.03$ for COPD. Four of these studies did not use healthy smokers as their control group or did not state whether the individuals in the control group were smokers [29, 32, 46, 47]. Therefore, data was only pooled from studies that compared COPD subjects with healthy smokers (fig. 2) and found an OR $\pm \mathrm{SE}$ of $1.29 \pm 0.04$ for COPD with the -308 SNP.

SNP frequencies for the -237 TNF SNP were also compared with other populations. Combining the present results with the pooled data from three other studies listed in table 1, the ORs 


\begin{tabular}{|c|c|c|c|c|}
\hline TABLE 4 & $\begin{array}{l}\text { ivariate and } r \\
\text { del) }\end{array}$ & ultivaria & e analyses (d & minant \\
\hline \multirow{2}{*}{$\begin{array}{l}\text { Genotype } \\
\text { comparison } \\
\text { COPD versus } \\
\text { control }\end{array}$} & \multicolumn{2}{|c|}{ Univariate analysis } & \multicolumn{2}{|c|}{ Multivariate analysis ${ }^{\#}$} \\
\hline & $\begin{array}{c}\text { OR } \\
(95 \% \mathrm{Cl})\end{array}$ & $p$-value & $\begin{array}{c}\text { OR } \\
(95 \% \mathrm{Cl})\end{array}$ & p-value \\
\hline $\begin{array}{c}-1031 \text { (CC or TC } \\
\text { versus TT) }\end{array}$ & $1.0(0.67-1.6)$ & 0.85 & $1.1(0.71-1.8)$ & 0.59 \\
\hline $\begin{array}{c}-863 \text { (AA or CA } \\
\text { versus } \mathrm{CC} \text { ) }\end{array}$ & $1.1(0.68-1.8)$ & 0.71 & $1.3(0.74-2.1)$ & 0.40 \\
\hline $\begin{array}{c}-857 \text { (TT or } \mathrm{CT} \\
\text { versus } \mathrm{CC} \text { ) }\end{array}$ & $0.83(0.48-1.5)$ & 0.52 & $0.70(0.39-1.3)$ & 0.24 \\
\hline $\begin{array}{c}-237 \text { (AA or } \mathrm{GA} \\
\text { versus } \mathrm{GG} \text { ) }\end{array}$ & $0.56(0.28-1.1)$ & 0.10 & $0.40(0.19-.86)$ & 0.02 \\
\hline $\begin{array}{c}-308 \text { (AA or GA } \\
\text { versus } \mathrm{GG} \text { ) }\end{array}$ & $1.9(1.1-3.2)$ & 0.03 & $1.9(1.1-3.4)$ & 0.03 \\
\hline $\begin{array}{c}+488 \text { (AA or GA } \\
\text { versus } \mathrm{GG})\end{array}$ & $1.8(0.78-4.3)$ & 0.17 & $1.7(0.71-4.2)$ & 0.23 \\
\hline
\end{tabular}

were not statistically significant either for all subjects (OR $\pm \mathrm{SE}$ $1.25 \pm 0.12$ ) or for the studies just comparing COPD subjects with smokers (OR \pm SE $1.22 \pm 0.14$; fig. 3).

\section{DISCUSSION}

TNF- $\alpha$ plays an integral role in the pathogenesis of COPD. In the present study, the most comprehensive haplotype evaluation to date using six single nucleotide polymorphisms in TNF was performed. These SNPs were chosen based on their association with changes in biological activity and result from previous studies in COPD. Some of these SNPs have been previously reported to be independently associated with COPD [29, 33, 41, 42, 44, 46]. For instance, it was confirmed that a genotype (GA or AA) with the minor allele of the -308 SNP was associated with a higher OR of having COPD, compared with smoking controls. Other SNPs (e.g. -237) and haplotypes were associated with a lower OR of having COPD or less severe disease.

The strongest association observed was for the most studied SNP, -308 (table 1). This SNP is in the promoter region of the TNF gene and is associated with increased gene transcription [18-23]. Although several earlier studies have shown an association of the -308 minor allele with COPD [33, 41, 42, 44, 46], four of these studies were in Asian populations [41, 42, $44,46]$ in which the minor allele frequency is much lower. The present study is only the second to show this association in Caucasians, the first being a large family study from the Boston early-onset COPD study [33]. Despite multiple studies showing positive associations, there are also 13 studies reporting no association between the -308 genotype (GA and AA) and COPD, including 10 in Caucasian populations [29-32, 34, 3739]. Previously, it was felt that the difference in studies were due to small sample size (underpowering) or low minor allele frequency [29]; however, a Forest plot (fig. 2) suggests that there is an association despite variability among populations.

Present study
BrøgGer [30]
HeRsh [33]
HIGHAM [36]
KEATINGs [35]
KüÇÜKAYCAN [29]
SEIFERT [34]
PATUZZO [32]
FERRAROTTI [39]
ISHII [43]
SAKAO [42]
JiANG [46]
HUANG [44]
CHIERAKUL [45]
HEGAB [40]
DANILKO [47]
Smokers only
Total

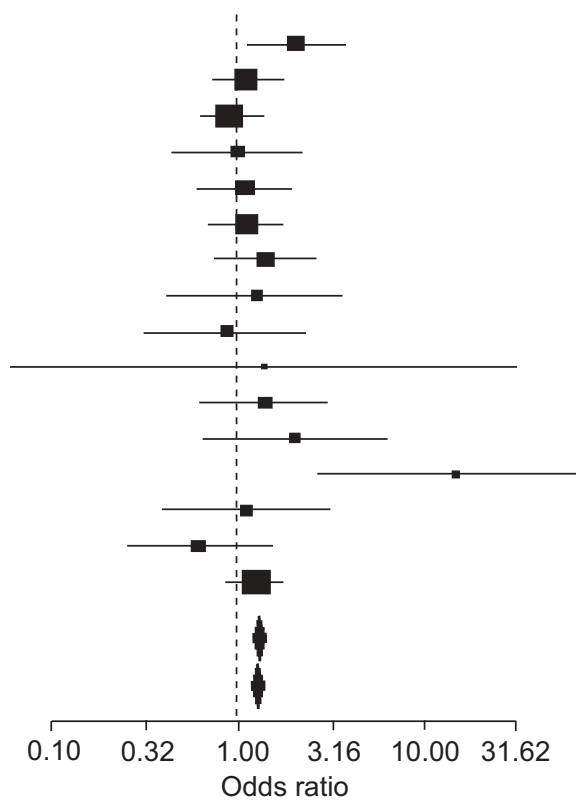

FIGURE 2. Forest plot of the odds ratio (OR) of having chronic obstructive pulmonary disease (COPD) with genotype of GA or AA of -307 single nucleotide polymorphism in the present study and previously published studies. Boxes indicate the point estimate and whiskers represent 95\% confidence intervals (Cls). The size of the box is proportional to the number of subjects in the study. Diamonds represent the combined ORs and $\mathrm{Cls}$ for all studies (total) and for studies comparing COPD patients with smoking controls (smokers only).

The second most significant association observed in the present study was with the -237 genotype (GA and AA). This SNP has been associated with decreased transcriptional activity and reduced TNF- $\alpha$ production from peripheral blood mononuclear cells [55]. The present multivariate analysis of Caucasian subjects showed that this genotype was less likely to be found in COPD subjects (7\% in controls versus $4 \%$ in COPD subjects). Previous studies have reported no association of this SNP with COPD [29, 30]; these studies had minor allele frequencies in controls (4 and 6\%, respectively), slightly lower than in the present study (7\%). In another study [33] the sample size was larger $(n=718)$, yet minor allele frequencies were also lower in control subjects $(4 \%$ for controls and $6 \%$ in cases; C. Hersh; Pulmonary and Critical Care Division, Brigham and Women's Hospital, Harvard Medical School, Boston, MA, USA; personal communication) suggesting that this association may have been due to a false-positive association (fig. 3).

Although other TNF SNPs appear to have biological activity in vitro, only two of these other SNPs $(-376$ and +488$)$ have been previously reported in COPD studies $[29,30,33,40]$. The +488 SNP has been associated with renal cell carcinoma [56] and prostate carcinoma [57]. This SNP is in the first intron of the TNF transcript but its significance is unclear [51, 58, 59]. In most studies there was no association between this SNP and COPD $[33,40]$ except for one study that compared COPD patients with healthy donors [29]. Surprisingly, this study found that the association between the $+488 \mathrm{SNP}$ and COPD was even stronger for COPD subjects that had none or limited radiographical evidence of the disease [29]. Although the -376 SNP was not 


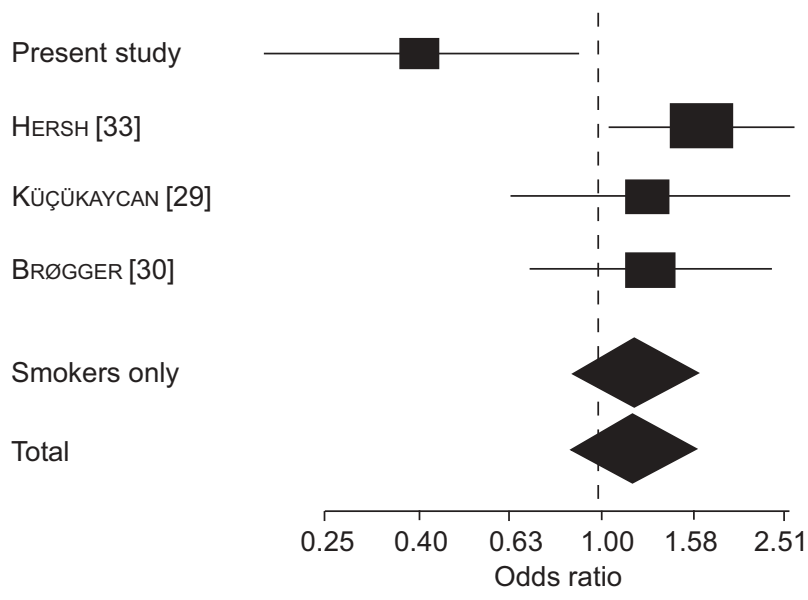

FIGURE 3. Forest plot of the odds ratio (OR) of having chronic obstructive pulmonary disease (COPD) with genotype GA or GA of -237 single nucleotide polymorphism in the present study and previously published studies. Boxes indicate the point estimate and whiskers represent 95\% confidence intervals (Cls). The size of the box is proportional to the number of subjects in the study. Diamonds represent the combined ORs and Cls for all studies (total) and studies comparing COPD patients with smoking controls (smokers only).

included in the present study, it is associated with an increase in TNF transcriptional activity and very strongly associated with an increased risk of cerebral malaria [60].

The present study is the first to report genotype frequencies of the -857 SNP in COPD, although it has been studied in other pulmonary diseases. This SNP is thought to be associated with decreased transcription by affecting binding of OCT1 and nuclear factor (NF)- $\kappa B$ transcription factors in the TNF promoter region, although reports have been conflicting [25, 61, 62]. Although in this investigation the OR for this SNP was not statistically significantly different, it was associated with mildto-moderate COPD (GOLD stages I and II). It is speculated that the $-857 \mathrm{~T}$ allele affects TNF- $\alpha$ production negatively in certain inflammation pathways using different transcription factors, thus leading to less inflammation of the airways and destruction of lung parenchyma: a model similar to that postulated for the gut in inflammatory bowel disease [61].

One strength of the present study is that multiple TNF SNPs were investigated and a haplotype analysis was conducted. Although only two SNPs were in significant LD, the haplotype block $-1031 /-863$ was found to be associated with COPD. This region of TNF is also thought to play a role in binding of OCT1 and NF- $\kappa \mathrm{B}$ transcription factors to the promoter region of TNF and the minor alleles are felt to cause increased TNF transcription [24, 25, 63]. The minor alleles for the -1031 and -863 SNPs have also been reported to be associated with gastric ulcers and gastric cancer [64]. In the haplotype in which COPD was found to be less likely, CC/TC $-1031 /-863$, the present authors hypothesise that several minor alleles at these sites make a patient less likely to have increased TNF- $\alpha$ production and, therefore, less likely to develop COPD.

In summary, the present study is one of the larger and more comprehensive studies of tumour necrosis factor polymorphisms in chronic obstructive pulmonary disease. It was confirmed that the well studied -308 single nucleotide polymorphism is associated with chronic obstructive pulmonary disease and other associations with the tumour necrosis factor gene were also reported, suggesting that tumour necrosis factor polymorphisms may play a role in the susceptibility to tobacco smoke. Additional large independent studies in both Caucasian and non-Caucasian populations are needed to replicate the present findings.

\section{ACKNOWLEDGEMENTS}

The authors would like to thank J. Orcutt, A. Jonth, C. Wheeler and M. Nicks (Dept of Medicine, National Jewish Medical and Research Centre, Denver, CO, USA), and R. du Bois and K. Welsh (Interstitial Lung Disease Unit, Royal Brompton Hospital, Imperial College of Science, Technology and Medicine, London, UK).

\section{REFERENCES}

1 Løkke A, Lange P, Scharling H, Fabricius P, Vestbo J. Developing COPD: a 25 year follow up study of the general population. Thorax 2006; 61: 935-939.

2 Koyama H, Geddes DM. Genes, oxidative stress, and the risk of chronic obstructive pulmonary disease. Thorax 1998; 53: Suppl. 2, S10-S14.

3 Silverman EK. Genetic epidemiology of COPD. Chest 2002; 121: Suppl. 3, 1S-6S.

4 Lundblad LK, Thompson-Figueroa J, Leclair $\mathrm{T}$, et al. Tumour necrosis factor- $\alpha$ overexpression in lung disease: a single cause behind a complex phenotype. Am J Respir Crit Care Med 2005; 171: 1363-1370.

5 Vuillemenot BR, Rodriguez JF, Hoyle GW. Lymphoid tissue and emphysema in the lungs of transgenic mice inducibly expressing tumour necrosis factor- $\alpha$. Am J Respir Cell Mol Biol 2004; 30: 438-448.

6 Churg A, Wang RD, Tai H, Wang X, Xie C, Wright JL. Tumor necrosis factor- $\alpha$ drives $70 \%$ of cigarette smokeinduced emphysema in the mouse. Am J Respir Crit Care Med 2004; 170: 492-498.

7 Churg A, Zay K, Shay S, et al. Acute cigarette smokeinduced connective tissue breakdown requires both neutrophils and macrophage metalloelastase in mice. Am J Respir Cell Mol Biol 2002; 27: 368-374.

8 Churg A, Wang RD, Tai H, et al. Macrophage metalloelastase mediates acute cigarette smoke-induced inflammation via tumour necrosis factor- $\alpha$ release. Am J Respir Crit Care Med 2003; 167: 1083-1089.

9 Mueller R, Chanez P, Campbell AM, Bousquet J, Heusser C, Bullock GR. Different cytokine patterns in bronchial biopsies in asthma and chronic bronchitis. Respir Med 1996; 90: 79-85.

10 Keatings VM, Collins PD, Scott DM, Barnes PJ. Differences in interleukin- 8 and tumor necrosis factor- $\alpha$ in induced sputum from patients with chronic obstructive pulmonary disease or asthma. Am J Respir Crit Care Med 1996; 153: 530-534.

11 Sun G, Stacey MA, Vittori E, et al. Cellular and molecular characteristics of inflammation in chronic bronchitis. Eur J Clin Invest 1998; 28: 364-372.

12 Aaron SD, Angel JB, Lunau M, et al. Granulocyte inflammatory markers and airway infection during acute 
exacerbation of chronic obstructive pulmonary disease. Am J Respir Crit Care Med 2001; 163: 349-355.

13 Daldegan MB, Teixeira MM, Talvani A. Concentration of CCL11, CXCL8 and TNF- $\alpha$ in sputum and plasma of patients undergoing asthma or chronic obstructive pulmonary disease exacerbation. Braz J Med Biol Res 2005; 38: 1359-1365.

14 Gan WQ, Man SF, Senthilselvan A, Sin DD. Association between chronic obstructive pulmonary disease and systemic inflammation: a systematic review and a metaanalysis. Thorax 2004; 59: 574-580.

15 Kuschner WG, D’Alessandro A, Wong H, Blanc PD. Dosedependent cigarette smoking-related inflammatory responses in healthy adults. Eur Respir J 1996; 9: 1989-1994.

16 McCrea KA, Ensor JE, Nall K, Bleecker ER, Hasday JD. Altered cytokine regulation in the lungs of cigarette smokers. Am J Respir Crit Care Med 1994; 150: 696-703.

17 Yamaguchi E, Itoh A, Furuya K, Miyamoto H, Abe S, Kawakami Y. Release of tumor necrosis factor- $\alpha$ from human alveolar macrophages is decreased in smokers. Chest 1993; 103: 479-483.

18 Bouma G, Crusius JB, Oudkerk Pool M, et al. Secretion of tumour necrosis factor $\alpha$ and lymphotoxin $\alpha$ in relation to polymorphisms in the TNF genes and HLA-DR alleles. Relevance for inflammatory bowel disease. Scand J Immunol 1996; 43: 456-463.

19 Louis E, Franchimont D, Piron A, et al. Tumour necrosis factor (TNF) gene polymorphism influences TNF- $\alpha$ production in lipopolysaccharide (LPS)-stimulated whole blood cell culture in healthy humans. Clin Exp Immunol 1998; 113: 401-406.

20 Braun N, Michel U, Ernst BP, et al. Gene polymorphism at position -308 of the tumor-necrosis-factor- $\alpha$ (TNF- $\alpha)$ in multiple sclerosis and it's influence on the regulation of TNF- $\alpha$ production. Neurosci Lett 1996; 215: 75-78.

21 Kroeger KM, Carville KS, Abraham LJ. The -308 tumor necrosis factor- $\alpha$ promoter polymorphism effects transcription. Mol Immunol 1997; 34: 391-399.

22 Wilson AG, Symons JA, McDowell TL, McDevitt HO, Duff GW. Effects of a polymorphism in the human tumor necrosis factor $\alpha$ promoter on transcriptional activation. Proc Natl Acad Sci USA 1997; 94: 3195-3199.

$23 \mathrm{Wu}$ WS, McClain KL. DNA polymorphisms and mutations of the tumor necrosis factor- $\alpha$ (TNF- $\alpha)$ promoter in Langerhans cell histiocytosis (LCH). J Interferon Cytokine Res 1997; 17: 631-635.

24 Udalova IA, Richardson A, Denys A, et al. Functional consequences of a polymorphism affecting NFкB p50-p50 binding to the TNF promoter region. Mol Cell Biol 2000; 20: 9113-9119.

25 Higuchi T, Seki N, Kamizono S, et al. Polymorphism of the 5 -flanking region of the human tumor necrosis factor (TNF)- $\alpha$ gene in Japanese. Tissue Antigens 1998; 51: 605-612.

26 Huizinga TW, Westendorp RG, Bollen EL, et al. TNF- $\alpha$ promoter polymorphisms, production and susceptibility to multiple sclerosis in different groups of patients. J Neuroimmunol 1997; 72: 149-153.

27 Pociot F, D'Alfonso S, Compasso S, Scorza R, Richiardi PM. Functional analysis of a new polymorphism in the human TNF $\alpha$ gene promoter. Scand J Immunol 1995; 42: 501-504.
28 Hajeer AH, Hutchinson IV. TNF- $\alpha$ gene polymorphism: clinical and biological implications. Microsc Res Tech 2000; 50: 216-228.

29 Küçükaycan M, Van Krugten M, Pennings HJ, et al. Tumor necrosis factor $\alpha+489 \mathrm{G} / \mathrm{A}$ gene polymorphism is associated with chronic obstructive pulmonary disease. Respir Res 2002; 3: 29.

30 Brøgger J, Steen VM, Eiken HG, Gulsvik A, Bakke P. Genetic association between COPD and polymorphisms in TNF, ADRB2 and EPHX1. Eur Respir J 2006; 27: 682-688.

31 Ruse CE, Hill MC, Tobin M, et al. Tumour necrosis factor gene complex polymorphisms in chronic obstructive pulmonary disease. Respir Med 2007; 101: 340-344.

32 Patuzzo C, Gilè LS, Zorzetto M, et al. Tumor necrosis factor gene complex in COPD and disseminated bronchiectasis. Chest 2000; 117: 1353-1358.

33 Hersh CP, Demeo DL, Lange C, et al. Attempted replication of reported chronic obstructive pulmonary disease candidate gene associations. Am J Respir Cell Mol Biol 2005; 33: 71-78.

34 Seifart C, Dempfle A, Plagens A, et al. TNF- $\alpha-$, TNF- $\beta-$, IL6-, and IL-10-promoter polymorphisms in patients with chronic obstructive pulmonary disease. Tissue Antigens 2005; 65: 93-100.

35 Keatings VM, Cave SJ, Henry MJ, et al. A polymorphism in the tumor necrosis factor- $\alpha$ gene promoter region may predispose to a poor prognosis in COPD. Chest 2000; 118 971-975.

36 Higham MA, Pride NB, Alikhan A, Morrell NW. Tumour necrosis factor- $\alpha$ gene promoter polymorphism in chronic obstructive pulmonary disease. Eur Respir J 2000; 15: 281-284.

37 Sandford AJ, Chagani T, Weir TD, Connett JE, Anthonisen NR, Paré PD. Susceptibility genes for rapid decline of lung function in the lung health study. Am J Respir Crit Care Med 2001; 163: 469-473.

38 Tanaka G, Sandford AJ, Burkett K, et al. Tumour necrosis factor and lymphotoxin $\alpha$ polymorphisms and lung function in smokers. Eur Respir J 2007; 29: 34-41.

39 Ferrarotti I, Zorzetto M, Beccaria M, et al. Tumour necrosis factor family genes in a phenotype of COPD associated with emphysema. Eur Respir J 2003; 21: 444-449.

40 Hegab AE, Sakamoto T, Saitoh W, et al. Polymorphisms of $\mathrm{TNF} \alpha$, IL1 $\beta$, and IL1RN genes in chronic obstructive pulmonary disease. Biochem Biophys Res Commun 2005; 329: 1246-1252.

41 Sakao S, Tatsumi K, Igari $H$, Shino $Y$, Shirasawa $H$, Kuriyama T. Association of tumor necrosis factor $\alpha$ gene promoter polymorphism with the presence of chronic obstructive pulmonary disease. Am J Respir Crit Care Med 2001; 163: 420-422.

42 Sakao S, Tatsumi K, Igari H, et al. Association of tumor necrosis factor- $\alpha$ gene promoter polymorphism with low attenuation areas on high-resolution CT in patients with COPD. Chest 2002; 122: 416-420.

43 Ishii T, Matsuse T, Teramoto S, et al. Neither IL-1 $\beta$, IL-1 receptor antagonist, nor TNF- $\alpha$ polymorphisms are associated with susceptibility to COPD. Respir Med 2000; 94: 847-851.

44 Huang SL, Su CH, Chang SC. Tumor necrosis factor- $\alpha$ gene polymorphism in chronic bronchitis. Am J Respir Crit Care Med 1997; 156: 1436-1439. 
45 Chierakul N, Wongwisutikul P, Vejbaesya S, Chotvilaiwan K. Tumor necrosis factor- $\alpha$ gene promoter polymorphism is not associated with smoking-related COPD in Thailand. Respirology 2005; 10: 36-39.

46 Jiang L, He B, Zhao MW, Ning LD, Li XY, Yao WZ. Association of gene polymorphisms of tumour necrosis factor- $\alpha$ and interleukin-13 with chronic obstructive pulmonary disease in Han nationality in Beijing. Chin Med J 2005; 118: 541-547.

47 Danilko KV, Korytina GF, Akhmidishina LZ, Ianbaeva DG, Zagidullin ShZ, Victorova TV. [Association of cytokines genes (ILL, IL1RN, TNF, LTA, IL6, IL8, IL0) polymorphic markers with chronic obstructive pulmonary disease.] $\mathrm{Mol}$ Biol (Mosk) 2007; 41: 26-36.

48 Hegab AE, Sakamoto T, Uchida Y, et al. Promoter activity of human tissue inhibitor of metalloproteinase 2 gene with novel single nucleotide polymorphisms. Respirology 2005; 10: 27-30.

49 Fabbri LM, Hurd SS, GOLD Scientific Committee. Global Strategy for the Diagnosis, Management and Prevention of COPD: 2003 update. Eur Respir J 2003; 22: 1-2.

50 Hankinson JL, Odencrantz JR, Fedan KB. Spirometric reference values from a sample of the general U.S. population. Am J Respir Crit Care Med 1999; 159: 179-187.

51 Fanning GC, Bunce M, Black CM, Welsh KI. Polymerase chain reaction haplotyping using $3^{\prime}$ mismatches in the forward and reverse primers: application to the biallelic polymorphisms of tumor necrosis factor and lymphotoxin ๙. Tissue Antigens 1997; 50: 23-31.

52 Grutters JC, Sato H, Pantelidis P, et al. Increased frequency of the uncommon tumor necrosis factor -857T allele in British and Dutch patients with sarcoidosis. Am J Respir Crit Care Med 2002; 165: 1119-1124.

53 Gabriel SB, Schaffner SF, Nguyen H, et al. The structure of haplotype blocks in the human genome. Science 2002; 296: 2225-2229.

54 Schaid DJ, Rowland CM, Tines DE, Jacobson RM, Poland GA. Score tests for association between traits and haplotypes when linkage phase is ambiguous. Am J Hum Genet 2002; 70: 425-434.
55 Kaluza W, Reuss E, Grossmann S, et al. Different transcriptional activity and in vitro TNF- $\alpha$ production in psoriasis patients carrying the TNF- $\alpha$ 238A promoter polymorphism. J Invest Dermatol 2000; 114: 1180-1183.

56 Nakajima K, Sasaki M, Nojima D, et al. Tumor necrosis factor- $\alpha$ gene mutations and genotype changes in renal cell carcinoma. J Urol 2001; 165: 612-615.

57 Oh BR, Sasaki M, Perinchery G, et al. Frequent genotype changes at -308 , and 488 regions of the tumor necrosis factor- $\alpha(\mathrm{TNF}-\alpha)$ gene in patients with prostate cancer. J Urol 2000; 163: 1584-1587.

58 D'Alfonso S, Richiardi PM. An intragenic polymorphism in the human tumor necrosis factor $\alpha$ (TNF $\alpha)$ chainencoding gene. Immunogenetics 1996; 44: 321-322.

59 Udalova IA, Nedospasov SA, Webb GC, Chaplin DD, Turetskaya RL. Highly informative typing of the human TNF locus using six adjacent polymorphic markers. Genomics 1993; 16: 180-186.

60 Knight JC, Udalova I, Hill AV, et al. A polymorphism that affects OCT-1 binding to the TNF promoter region is associated with severe malaria. Nat Genet 1999; 22: 145-150.

61 van Heel DA, Udalova IA, De Silva AP, et al. Inflammatory bowel disease is associated with a TNF polymorphism that affects an interaction between the OCT1 and NF- $\mathrm{BB}$ transcription factors. Hum Mol Genet 2002; 11: 1281-1289.

62 Uglialoro AM, Turbay D, Pesavento PA, et al. Identification of three new single nucleotide polymorphisms in the human tumor necrosis factor- $\alpha$ gene promoter. Tissue Antigens 1998; 52: 359-567.

63 Skoog T, van't Hooft FM, Kallin B, et al. A common functional polymorphism (C-->A substitution at position -863 ) in the promoter region of the tumour necrosis factor- $\alpha$ (TNF- $\alpha$ ) gene associated with reduced circulating levels of TNF- $\alpha$. Hum Mol Genet 1999; 8: 1443-1449.

64 Sugimoto M, Furuta T, Shirai N, et al. Different effects of polymorphisms of tumor necrosis factor- $\alpha$ and interleukin$1 \beta$ on development of peptic ulcer and gastric cancer. J Gastroenterol Hepatol 2007; 22: 51-59. 